\title{
The Effect of Internationalization and Learning Orientation on the Quality of Accounting Learning with Self-Direct Learning as a Moderating Variable
}

\author{
Firda Nurhidayati ${ }^{1}$, Dwi Puji Astuti ${ }^{1, *}$ \\ ${ }^{I}$ Economic Education, Faculty of Economic, Universitas Negeri Semarang \\ *Corresponding author.Email: dpastuti@mail.unnes.ac.id
}

\begin{abstract}
This research aims to find out the influence of internationalization, learning orientation on the quality of learning. As well as the role of self-direct learning variables as moderation variables to strengthen the influence of digital literacy variable, internationalization, learning orientation to the quality of learning. The population in this study was accounting education students from 2016 to 2019 . This population is selected using purposively. The data required in this study is primary data obtained through a closed interview, observation, and questionnaire techniques. Data analysis techniques use descriptive analysis and moderation regression with absolute difference tests. The results showed that internationalization has no effect on any variable the quality of learning, learning orientation affects the quality of learning and the introduction of self-direct learning variables as moderation variables are not able to strengthen the positive and significant influence on the quality of learning. The advice in this study is for future research to develop other independent variables that are likely to affect the quality of learning. Besides, the next study is to increase the number of respondents for the next study. Advice for students that orientation as an effort to improve internationalization related to improving the quality of learning of students of accounting education department class 2016-2019 UNNES needs to be improved.
\end{abstract}

\section{Keywords: Internationalization, Learning Orientation, Self-Direct Learning, Learning Quality}

\section{INTRODUCTION}

A learning process is often faced with problems related to the quality of learning. The quality of learning depends on the ability of educators to develop effective and efficient learning processes. In achieving these goals, in learning activities, two essential aspects must be considered, namely the aspect of the learning process and the aspect of learning outcomes.

The primary purpose of organizing learning activities operationally is to teach students to be able to process and acquire knowledge, skills, and attitudes for themselves. This means that in order to achieve a good quality of learning, the lecture materials must be arranged with the right strategy and delivered to students with the right delivery strategy that anyway. The quality of learning is also influenced by the orientation of learning, internationalization and also the independence of learning in students.

\section{LITERATURE REVIEW}

The internationalization of universities is a process that concerns the internationalization of the curriculum, administration and management, academic collaboration research, and exchange of students, and lecturers [1]. The Ministry of Education and Culture has strongly encouraged all schools to use digital devices to support the teaching process and to improve the quality of learning outcomes in schools. Also, the language policy applies in Indonesia with the teaching of English. This policy is made, assuming that it is better to learn English earlier for children because they are more comfortable and faster to master a foreign language than adults [3]. [6] mentioned that five factors affect the quality of learning; one of the factors is the internationalization of universities.

The orientation aspect of learning also plays an essential role in the success of the quality of learning. They are learning orientation or reasons that encourage a person to learn. It is the affective dimension of the learning process that also determines the quality of students' 
learning outcomes. Because the orientation of learning has a strong effect on the quality of learning outcomes, some surveys (in the context of secondary and higher education) confirm that learning orientation is generally associated with academic achievement. According to [13], the results of his research show that learning orientation is positively correlated with academic achievement. These findings are consistent, broadly, with empirical findings of qualitative research from [9] which is that a person with a learning orientation with an indepth learning approach will be comfortable in gaining understanding. An in-depth learning approach consistently correlates positively with academic achievement [8].

Accounting education students as prospective accounting educators have a responsibility to have to update and practice the knowledge obtained in the world of education. Based on the observation of researchers to the phenomenon in the Accounting Education Department of the Faculty of Economics UNNES, students who succeed in the process of working on the task are students who have Self Directed Learning. The term SDL is widely found in the psychology literature of adult education [5]. According to [2], SDL is a skill in which a person can determine himself and choose the goals he or she wants to achieve, plan strategies to be done, strive to solve problems, management himself, and evaluate the thinking and performance that has been done. The results of research conducted by [4] revealed that SDL has a positive influence on academic performance in undergraduate and postgraduate students. Self-Directed Learning (SDL) is also needed for students to complete tasks [11].

The quality of learning becomes a strategic goal for every higher education institution. Many higher education institutions apply specific learning and have designed mechanisms and instruments to improve the quality of education. More specifically, the purpose of this study is to analyze the application of learning quality with predictors of internationalization use and learning orientation in accounting learning with Self Direct Learning (SDL) as a moderating variable.

\section{METHOD}

This research uses a mixed-methods approach; the paradigm is pragmatism with a combined method between quantitative and qualitative [12]. The type of research used is a case study or field study which is intended to study intensively about the background of current circumstances and positions as well as the environmental interactions of specific social units that are what they are [1]. This research starts from data collection, compiled, analyzed and synthesized to then be concluded and presented in the form of reports.

The primary data in this study was obtained through interview, observation, and by giving questions (questionnaires) in writing both open and closed. Observations are directed at self- direct learning assessment, campus internationalization, and learning orientation. The secondary data required in this study was obtained through documentation techniques. The data obtained is further interpreted and used to amplify information and events that occur in the field during interviews and observations. As for in this study took the location of the work unit of UNNES focused on accounting education study program. The population in this study was selected purposively. The population consists of 437 Accounting Education students from 2016 to 2019. There are 109 students in 2016. There are 93 students in 2017. There are 120 students in 2018; there are 115 students in 2017.

\section{DISCUSSION}

Analysis of moderation regression models in this study used absolute difference testing techniques to test the influence of dependent, independent, independent and moderation variables. Test the absolute difference in this study using the IBM SPSS statistic 26.0 software application. The level of significance used is 0.05 . Based on these results that the moderation regression model can be presented in the following Table 1:

Table 1. The Moderation Regression Test Result

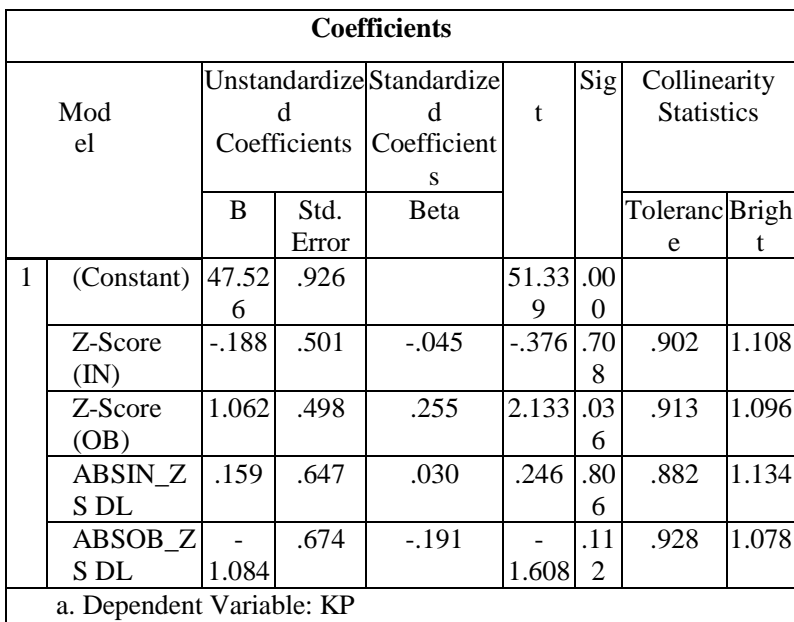

Source: Research data, 2020.

\section{The Influence Internationalization on the Quality of Student Learning in the Accounting Education Department}

Based on the results of this study, it can be seen that the significant partial test (t-test) variable internationalization of the learning quality of students of the Department of Accounting Education Class 20162019 has a significance value of 0.708 and a coefficient value of -0.188 . Based on the results of this study can be explained that the internationalization is not significant to the quality of student learning of the Accounting Department of Education $\mathrm{n}$ Accounting Force 20162019. Therefore, $\mathrm{Ha}_{1}$ is rejected.

The results of this study are irrelevant to the theory of Astin I-E-O. Student outcomes are determined by input and environment. In this study, there is a right 
internationalization environment does not always affect the outcome or quality of learning well as well. Based on the descriptive analysis of the internationalization of the Department accountable Education UNNES class of 2016-2019 understands that he has internationalization and quality good learning. The fact that the environment does not affect the outcome of this study is the quality of learning. This is because based on the data of research respondents that there are still $9.33 \%$ not master digital applications that can hinder learning to realize internationalization. Besides, education in several countries has failed in its application to keep pace with the tide of change brought about by globalization. These failures are due to limited resources, low teacher numbers, to pressure and time for teachers. [7] Stated that policymakers also need to pay attention to critical contextual factors that can determine the success rate of higher education internationalization policies, namely opportunities, imperatives, barriers, and resources.

This view is reasonable, given that internationalization not only provides hope and opportunity for a Country but destroys the joints of the State. This led to internationalization did not affect the quality of learning.

\section{The Effect of Learning Orientation on the Quality of Learning of Students in Accounting Education Department}

Based on the results of this study, it can be seen that the significant partial test ( $t$-test) variable orientation of learning on the quality of learning of students of the Department of Accounting Education Class 2016-2019 has a significance value of 0.036 and a coefficient value of 1,062. Based on the results of this study explain that the orientation of learning is significant. The second hypothesis is acceptable.

The theory of Astin I-E-O supports the results of this study. Student outcomes are determined by input and environment. This theory explains at the same time. Input factors have relationships that will affect the environment and affect outcomes. Based on descriptive analysis results proves that students of the Accounting Education Department class of 2016- 2019 have the right learning orientation and learning quality. Motivation is divided into two kinds in the learning process, namely intrinsic motivation and extrinsic motivation [10]. This can lead to a very high learning orientation affecting the quality of learning. The orientation of outdoor learning is done to fulfil obligations, avoid punishment, earn rewards, increase prestige, and to earn praise. This has an impact on the initial goal that there is a learning orientation as fulfilment for the improvement of the quality of learning. According to [9] the way a person learns and the approach taken to learning can be influenced by some things such as motivation. Motivation is divided into two internal and external.

\section{The Influence Self Direct Learning in Strengthening the Influence of Internationalization on the Quality of Learning of Students in Accounting Education Department}

Based on this research can be seen that the significant test partial ( $\mathrm{t}$-test) variable moderation variable between internationalization and self-direct learning has a significance value of 0.806 . This variable self-direct learning as a moderation variable does not successfully moderate the internationalization relationship to the quality of learning of students of the Department of Accounting Education Class 2016-2019. In conclusion, based on the results of $\mathrm{Ha}_{3}$, rejected.

The theory of Astin I-E-O did not successfully support the results of this study. Student outcomes are determined by input and environment. In this study, internationalization variables related to environment and self-direct learning as input. Facts show based on the results of descriptive analysis of internationalization in high categories, and variable self-directed learning (SDL) are in very high categories. This is because, in the face of the context of education in Indonesia, the impact of internationalization can be seen from several things. It was shown in the data of the study respondents that there were 68 people or $90.66 \%$ of them stated that they mastered digital applications. However, mastery of their application is more widely used to play social media only, communication, and others. The internationalization that students have as input does not affect the limited quality of learning as an outcome. When that happens, and self-direct learning comes across as a moderation variable, the same results have not succeeded in strengthening the influence of internationalization. This is because the internationalization factor requires not only the cooperation of lecturers and students but many people, many media, and others. This is what is felt less and makes internationalization does not affect the quality of learning, even when self-direct learning is present as a moderation variable.

\section{The Influence of Self Direct Learning in Strengthening the Influence of Learning Orientation on the Quality of Learning of Students in Accounting Education Department}

Based on this research can be seen that the significant test partial (t-test) variable moderation variable between learning orientation and self-direct learning with digital literacy has a significance value of 0.112 , variable the variable self-direct learning as a moderation variable does not succeed in moderating the relationship of learning orientation to the quality of learning students of the Department of Accounting Education Class 20162019. Based on those results that $\mathrm{Ha}_{4}$ that, rejected.

The results of this study are irrelevant to the theory of Astin I-E-O. This theory states that student outcomes are 
determined by input and environment. It is targeted by descriptive analysis that the variables of learning orientation and self-directed learning (SDL) in the category are very high. This shows that the very high orientation of learning supported by self-directed learning does not affect the high quality of learning as well. This is because learning orientation is related to learning motivation, both intrinsic and extorting [10]. When a person has a high learning orientation because of outside motivation, it will affect the quality of learning. However, when it happens and supported by selfdirected learning as a student is as readiness to his learning environment and self-reliance that demands students to learn, then the quality of learning turns out to be insignificant. This is because the student's learning orientation is considered to have sufficiently affected the quality of learning. Responsibly and independently students learn but not necessarily they understand the learning process themselves can happen because the orientation of learning students from outside higher that is forced because of lecturers, gifts etc.

\section{Determinant Coefficient $\left(\boldsymbol{R}^{2}\right)$}

Determination coefficients are used to measure the ability of models to describe dependent variations. The ability of independent variables to describe dependent variables is limited if the $\mathrm{R}^{2}$ value is smaller. The results of simultaneous determination tests in this study are as follows:

Table 2. Determination Coefficient Results

\begin{tabular}{|c|c|c|c|c|}
\hline \multicolumn{5}{|c|}{ Model Summary } \\
\hline Model & $\mathrm{R}$ & R Square & $\begin{array}{c}\text { Adjusted R } \\
\text { Square }\end{array}$ & $\begin{array}{c}\text { Std. The error } \\
\text { of the } \\
\text { Estimate }\end{array}$ \\
\hline 1 & $.295^{\mathrm{a}}$ & .087 & .035 & 4.090 \\
\hline $\begin{array}{l}\text { a. Predictors: (Constant), ABSOB_ZSDL, Z-score (IN), } \\
\text { Z-score (OB), ABSIN_ZSDL }\end{array}$
\end{tabular}

\section{Source: Research data, 2020}

Based on the output software, IBM SPSS statistic 26.0 can be known the value of Adjusted $R$ square 0.035 or $3.5 \%$. The results showed that $3.5 \%$ of learning quality variables were explained by variations in internationalization, learning orientation, and selfdirected variables. Other factors outside this research model explain a total of $96.5 \%(100 \%-3.5 \%)$ learning quality variables.

\section{CONCLUSION AND SUGGESTION}

Based on the results of the analysis and discussion stipulated in this study, it can be concluded that internationalization variables do not influence the quality of learning, but influence variables of learning orientation of accounting education students in the class of 2016-2019. Furthermore, the presence of variables self-direct learning as moderation variables is not able to strengthen the influence of internationalization variables, and the orientation of learning to the learning quality of students Accounting Education class of 2016-2019.
The results of this study can advise further research to be able to develop other independent variables that are likely to affect the quality of learning and can multiply the number of respondents so that it is expected that the results obtained can be more accurate and describe the actual circumstances. Based on the data of respondents internal learning orientation, as the mastery of digital applications as an internationalization effort mastered by students related to improving the quality of learning of students of the Accounting Education Department in 2016-2019 UNNES needs to be improved.

\section{REFERENCES}

[1] Danim, S. Menjadi Peneliti kualitatif. Bandung: Pustaka Setia. 2002.

[2] Gibbons, M. The self-directed learning handbook: Challenging adolescent. 2002.

[3] Hsu, Y. C., \& Shiue, Y. M. The Effect of SelfDirected Learning Readiness on Achievement Comparing Face-to-Face and Two-Way Distance Learning Instruction. International Journal of Instruction Media, 32 (2), 143-148. 2005.

[4] Hyland, N \& Kranzow, J. Faculty and Student Views of Using Digital Tools to Enhance Self-Directed Learning and Critical Thinking. International Journal of Self-Directed Learning, 8 (2). 2011.

[5] Jossberger, H., Brand-Gruwel, S., Boshuizen, H., \& Wiel, M. The challenge of self- directed and selfregulat Sed learning in vocational education: a theoretical analysis and synthesis of requirements. Journal of Vocational Education and Training, 62 (4), 415-440. 2010.

[6] Jun Liu. College of Foreign Languages, North China Electric Power University No 2, BeinongRoad,Huilongguan,Changping District, Beijing.

[7] Liu, J. On the Internationalization of Higher Education Institutions in China on the Internationalization of Higher Education Institutions in China. 2015.

[8] Marton, F., \& Saljo, R. Approaches to learning. In F. Marton, D. Hounsell \& N. Entwistle (Eds.). The experience of learning: Implications for teaching and studying in higher education. 39-58. 2005.

[9] Sardiman. Interaksi dan Motivasi Belajar Mengajar. Jakarta: PT. Raja Grafindo Persada. 2007.

[10] Ushfuriyah. Hubungan Antara Dukungan Sosial Dengan Optimisme Mahasiswa Fakultas Psikologi UIN Maulana Malik Ibrahim Malang Dalam Menyelesaikan Skripsi. Jurnal Fakultas Psikologi UIN Maulana Malik Ibrahim Malang. 12 (1). 2015

[11] Tashakkori, A \& Charles Teddlie. Mixed Methodology. Yogyakarta: Pustaka Belajar. 2010.

[12] Vermunt, J. D., \& Vermetten, Y. J. Patterns in student learning: Relationships between learning strategies, conceptions of learning, and learning orientations. Educational Psychology Review, 16 (4), 359- 384. 2004. 